\title{
Comparative analysis of hydrologic signatures in two agricultural watersheds in east-central Illinois: legacies of the past to inform the future
}

\author{
M. A. Yaeger $^{1}$, M. Sivapalan ${ }^{1,2}$, G. F. McIsaac ${ }^{3}$, and X. Cai ${ }^{1}$ \\ ${ }^{1}$ Department of Civil and Environmental Engineering, University of Illinois at Urbana-Champaign, Urbana, IL, USA \\ ${ }^{2}$ Department of Geography, University of Illinois at Urbana-Champaign, Urbana, IL, USA \\ ${ }^{3}$ Department of Natural Resources and Environmental Sciences, University of Illinois at Urbana-Champaign, Urbana, \\ IL, USA \\ Correspondence to: M. A. Yaeger (yaeger3@illinois.edu)
}

Received: 5 May 2013 - Published in Hydrol. Earth Syst. Sci. Discuss.: 27 May 2013

Revised: 13 September 2013 - Accepted: 24 October 2013 - Published: 21 November 2013

\begin{abstract}
Historically, the central Midwestern US has undergone drastic anthropogenic land use change, having been transformed, in part through government policy, from a natural grassland system to an artificially drained agricultural system devoted to row cropping corn and soybeans. Current federal policies are again influencing land use in this region with increased corn acreage and new biomass crops proposed as part of an energy initiative emphasizing biofuels. To better address these present and future challenges it is helpful to understand whether and how the legacies of past changes have shaped the current response of the system. To this end, a comparative analysis of the hydrologic signatures in both spatial and time series data from two central Illinois watersheds was undertaken. The past history of these catchments is reflected in their current hydrologic responses, which are highly heterogeneous due to differences in geologic history, artificial drainage patterns, and reservoir operation, and manifest temporally, from annual to daily timescales, and spatially, both within and between the watersheds. These differences are also apparent from analysis of the summer low flows, where the more tile-drained watershed shows greater variability overall than does the more naturally drained one. In addition, precipitation in this region is also spatially heterogeneous even at small scales, and this, interacting with and filtering through the historical modifications to the system, increases the complexity of the problem of predicting the catchment response to future changes.
\end{abstract}

\section{Introduction}

The Renewable Fuel Standard (RFS), a provision of the US Energy Policy Act of 2005, mandated 7.5 billion gallons of renewable fuels by 2012 , and was subsequently expanded to require 36 billion gallons by 2022 . This mandate has created and increased the demand for biofuels, leading to an increasing demand for biofuel refinery feed-stocks. Since current biofuel production consists mainly of corn-based ethanol, this has led to a rapid expansion in corn-planted area, the majority of which is found in the Corn Belt, a fertile, humid region in the Midwestern US, comprising portions of the upper Mississippi River basin as well as portions of the Ohio River basin. Recent studies (Donner et al., 2004; David et al., 2010), however, have pinpointed this region as the source of the majority of nitrate exported to the Gulf of Mexico, which is a cause of the large hypoxic zone at the mouth of the Mississippi River. Amid concern over increasing nitrate levels resulting from increased corn crop fertilization (Donner and Kucharik, 2008), the RFS has recently been expanded to now include a mandate for second generation biofuels, providing further motivation for research into alternative feed-stocks for refining biofuels. Of these, perennial biomass crops such as Miscanthus giganteus and switchgrass, grown for cellulose-based ethanol production, have shown much promise. Both field experiments (McIsaac et al., 2010; Smith et al., 2013) and watershed-scale modeling experiments (Ng et al., 2010) have shown that less nitrate is exported from Miscanthus compared to conventional 
corn crops. However, recent field experiments (McIsaac et al., 2010; Hickman et al., 2010) and canopy-scale modeling studies (Le et al., 2011) have also shown that water usage by Miscanthus is significantly greater than that of corn or soybeans. If large-scale planting of these biomass crops is to be sustainable, it is essential to understand how watersheds as a whole might respond to this change and be aware of possible negative outcomes.

This switch to perennial grasses on the scale required to meet the cellulosic ethanol demand set forth in the RFS may cause a major change to the agriculture which then will impact the hydrologic processes in the region. What the future hydrologic responses to biofuel development in the region will be remains a concern. To address this question, a regular approach is to develop a hydrologic model of the region, calibrate it to observed data, and then run scenarios based on the proposed changes. Given that this region has experienced similar major changes in the past, we suggest that before commencing such modeling efforts, much can be learned from a detailed analysis of historical changes to this region that led to the current conditions. Once the history of a watershed is known, more recent data can be analyzed to find the hydrologic signatures of these past changes and this knowledge can then be used to inform the modeling process. The purpose of this study, then, is to examine the legacy of past changes in two typical Corn Belt watersheds to gain a deeper understanding of the watershed response in order to better predict the response under the proposed changes.

This paper is comprised of four main sections. In the first, we have introduced the motivation for the study; the second provides a historical perspective of the natural and anthropogenic changes already imposed on this region as well as the environmental and anthropogenic responses to those changes. Section 3 describes the data used, spatial characteristics of the study watersheds, and the methods used in this study; the results of this comparative analysis are presented in Sect. 4. In Sect. 5 we discuss the findings and how they can be applied to the problem of predicting future changes. We conclude with a discussion of the limitations of using observed data for the purposes of prediction and a preview of future work that can overcome these limitations.

\section{Historical impacts and environmental feedbacks}

The central Midwestern US presents rich examples of both natural and anthropogenic changes and corresponding environmental feedbacks. Each of these changes left its imprint on the geology, hydrology, and vegetation of this region, and these signatures can be found throughout the historical record and in the data. If we consider the region, at least from human settlement onward, as a coupled human-nature system, its history can be visualized as a series of impact/feedback loops that spiral forward in time. The proposed crop changes, then, would be the most recent in a region which has undergone many such changes in the past, often to the detriment of the surrounding environment. Through analysis of past human impacts and environmental responses we can gain a better understanding of the dynamics of this coupled system, and therefore make more informed predictions about the responses to impacts of the new biofuels crops.

\subsection{Pre-European settlement to 1850: wet prairies}

Before humans became established in the Midwest, the region was subject to natural impacts that influenced the coevolution of soils and vegetation and resulting hydrologic conditions. In the last 1.6 million years, much of the region, including most of the state of Illinois (IL) was at some point covered by glaciers, and in some places, more than once. As the glaciers retreated, land cover became more forested as tree species from the south and east migrated to the region through seed dispersal, although further climate fluctuations, aided by fire, provided natural disturbances that kept the system in flux between grassland and forest (Whitney, 1994). Warmer, drier climate periods favored grassland development, while forests tended to expand in cooler, more humid climate periods where topography allowed, since underlying geology also played an important role in the vegetation and soils that co-evolved in the Midwest. The most recently glaciated regions were dominated by flat or slightly depressed areas overlaying clayey deposits that collected spring precipitation and remained saturated well into the summer, thus preventing establishment of woody vegetation such as trees, which are less tolerant to prolonged waterlogging. The natural condition of this region, therefore, was a shifting mosaic of grassland and forest that changed in response to climate fluctuations and fire frequency under the constraints of soil properties (Whitney, 1994; Prince, 1997; Woodhouse and Overpeck, 1998).

There is strong evidence that the first major human impacts to this region were not due to the European settlers but rather to the extensive use of fire by early humans to modify the landscape by suppressing forest in favor of grassland (Whitney, 1994; Prince, 1997). Thus when settlers began arriving in IL in the early to mid-19th century they found a region dominated by wet grassland in the north and east, with forest dominating in the south and along stream channels (Fig. 1a). From the extensive writings of surveyors and natural historians who arrived before and with the settlers, we have some idea of the state of the system before the next phase of human modifications took place. Because of the geologic history of glaciation, large portions of the region, especially the uplands, tended to be flat and covered with silty clayey soils overlaying a hardpan subsoil layer; thus much of the region lacked a well-defined drainage network and the soil column was saturated in places for long periods during the year. The dominant vegetation consisted of tall grasses whose dense root systems held the fine soil particles in place, minimizing erosion from the often intense precipitation, and aiding 

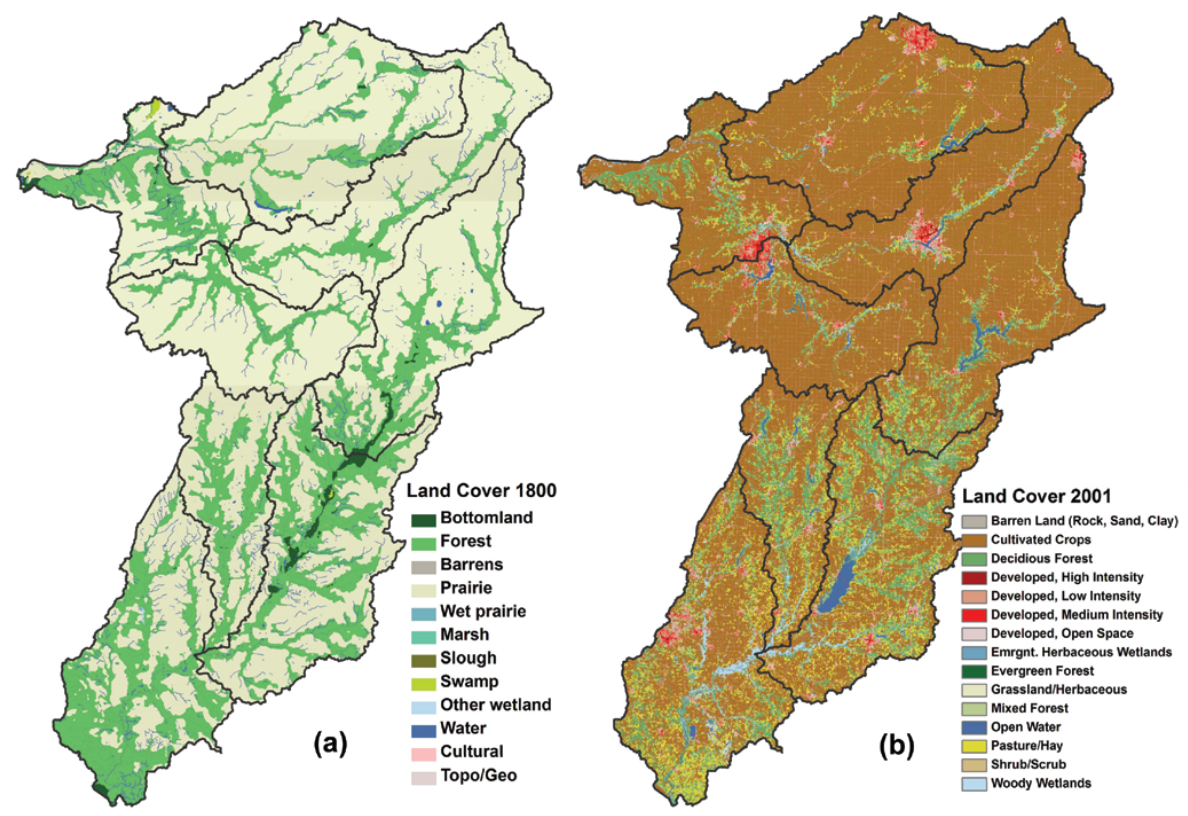

Fig. 1. Land cover change in two watersheds in central IL: pre-European settlement land cover (a) and present-day (b).

in the retention of soil moisture in dry years. This formation of high-density root mats, or sod, also posed one of the first major challenges to agricultural development by early European settlers, since plows of the time were unable to cut through it (Prince, 1997). Furthermore, precipitation falling on the vast, poorly drained wet prairie regions would saturate the soil and then pool on the surface, from where it either infiltrated into the soil or evaporated (Prince, 1997; Jackson, 2002). In addition, wet soils provided the necessary anoxic conditions for denitrification, which removes available nitrate-nitrogen from the shallow groundwater (McIsaac and $\mathrm{Hu}, 2004)$. Thus, at the time of settlement, the natural condition of most of the region was a retentive, absorbent ecosystem characterized by long residence times, and where inputs, both of precipitation and nutrients (in the form of decaying organic matter), were highly filtered and processed by the catchment (Karlen et al., 2010).

\subsection{Impacts and feedbacks: 1850-1945}

From the point of view of the early European settlers, these wetland regions were useless for agriculture, and worse, were sources for malaria and other diseases (Bogue, 1951; Prince, 1997). The US Congress passed the Swampland Act of 1850 , mandating that these "useless" wetlands be given to the individual states to be sold, drained, and converted to productive agricultural land. However, it was not until nearly the end of the 19th century before this was extensively accomplished. Initial efforts to drain the land by digging ditches had some success, but it was the combination of surface and subsurface drainage that proved most effective in the wet prairie regions. The passage of local laws forming drainage districts that shared the cost of improvements among all landowners, coupled with the local production of drainage tiles (Bogue, 1951) provided the impetus for the second major human impact on this region: extensive artificial drainage of Midwestern wetlands and their conversion to cropland. Tile drainage lowered the water table by quickly moving water out of the soil column once it reached the level of the drains (Goswami et al., 2008); the excess water was then removed from agricultural fields by an extensive network of drainage ditches dug to connect the tile outlets to existing channels, which were often then dredged and straightened to accommodate the increased flow (White et al., 2003; Royer et al., 2006; Van der Velde et al., 2010). In hydrologic terms, this greatly increased the drainage density (defined as the ratio of the total length of all stream channels to the total area drained) of the system. The end result of these changes was a switch from a retentive, poorly drained system to a leaky, well-drained one.

With the rich soil now dry enough for crops and aided by an earlier development of special "sod-busting" plows to cut through the prairie grass root mats (Bogue, 1994), by 1900 agriculture became the dominant land use in the region, and until about 1945, consisted of annual crops such as corn in rotation with sod-based crops such as oats or hay (Jackson, 2002). This replacement of the tall-grass prairie with agricultural crops resulted in the destruction of the grass root networks that had held the fine soils together. Freshly plowed and seeded land was highly vulnerable to rainfall erosion, especially in the humid Midwest where precipitation peaks in the late spring, and soil moisture is often near field capacity. Although soil losses were noticeable, and there were scattered attempts at conservation, many people at the time 
viewed the land as a vast, inexhaustible resource, and simply moved on when crop yields in one location declined (Trimble, 1985; Whitney, 1994). In this way, agricultural expansion continued westward, into a windy, semiarid climate for which the current farming practices were poorly suited (Baumhardt, 2003). Beginning in 1931, over twothirds of the country, including the Midwest, experienced a severe drought (Woodhouse and Overpeck, 1998); this, coupled with the effects of years of poor land management, resulted in the loss of much of the topsoil in the western Great Plains in what is now known as the Dust Bowl (Schubert et al., 2004). Although the massive environmental damage, itself one of the first major environmental feedbacks on the impacts of human agricultural activities (Cook et al., 2009; Karlen et al., 2010), was limited to the Great Plains west of the Mississippi River, it was a national economic disaster affecting the entire farm economy. It was the magnitude of the effects of the Dust Bowl that finally prompted a concerted human system response to the problem of soil erosion. In 1933, the US government formed the Soil Erosion Service (later, Soil Conservation Service) to determine the causes and extent of soil erosion in the US, and then go out and teach farmers across the country, including those in the Midwest, better soil management practices. As a result, soil erosion was significantly reduced (Turner and Rabalais, 2003; Karlen et al., 2010), with soil conservation efforts continuing to the present-day.

\subsection{Impacts and feedbacks: 1945 -present}

The next series of major land use changes began around 1945 and have continued to the present-day. In 1944 and 1945, the US government enacted two flood control acts that spurred another tile drainage development period by engaging federal agencies in land drainage work as part of their flood prevention and soil conservation missions (Wooten and Jones, 1955; Karlen et al., 2010). In addition, as tractors replaced horses, soybeans began to replace oats and hay in rotation with corn (Jackson, 2002; McIsaac and Hu, 2004), leading to the current land use configuration shown in Fig. 1b. As large-scale row crop agriculture expanded in this region, inputs of nutrients - mainly nitrate-nitrogen and phosphorus - to the system greatly increased. The change from annual crops in rotation with sod crops to a rotation of only annual row crops decreased annual evapotranspiration (ET) by shortening the growing season, and this, coupled with increasing tile drainage density, has likely increased baseflow to local streams (Zhang and Schilling, 2006). Over this same period, annual precipitation in the Midwest has been increasing (Raymond et al., 2012), contributing to higher streamflow overall. The effect of tile drainage was to decrease soil residence times by moving water more quickly through the subsurface to the stream, thus bypassing natural biogeochemical processes that reduce the nitrate concentration in soil pore water (McIsaac and Hu, 2004; Panno et al.,
2008). Furthermore, the majority of nutrient export occurs during periods of high discharge (Royer et al., 2006) when in-stream removal by denitrification processes is least efficient (Royer et al., 2004). In addition, wet years can result in nitrate flushing from the system, where nitrate stored in the soil during drier years is mobilized in addition to that from the current year's fertilizer application (Gentry et al., 2009). The combination of climate and land use changes and the hydrologic modification of the landscape have resulted in a marked increase of nutrient export from the Midwest region to the Mississippi River (David et al., 2001). A notable exception to this general regional pattern are those streams with large, inline reservoirs; since reservoirs act to increase residence times, significant denitrification can take place, in some cases removing nearly $50 \%$ of the nitrate (David et al., 2006).

Similar to the problem of increasing soil erosion earlier in the century, the effects of increased nutrient export from Midwestern agricultural watersheds initially manifested locally. Levels of nitrate in excess of US drinking water standards were frequently found in surface water bodies in the region (Smith et al., 1993; Kalita et al., 2006), including those used for municipal water supply (Keefer et al., 2010). As before, the human system response to the problem tended to be localized, although some national attention was paid. Much like the Dust Bowl, it was not until large-scale environmental damage with national economic implications became evident that a concerted effort was made to respond. The appearance of a persistent, recurring hypoxic zone threatening important US fisheries in the Gulf of Mexico was a second, and more direct, major environmental feedback on the impacts of human agricultural activities (Goolsby et al., 1999; David et al., 2010). While soil conservation practices implemented after the Dust Bowl may have decreased the export of Midwestern soils in rivers and streams, they have had little effect on nitrogen export. Thus, as was the case in the 1930s, solutions for shrinking or preventing the formation of the hypoxic "Dead Zone" must involve large-scale modification of agricultural practices, this time to drastically reduce the export of nutrients from tile-drained watersheds in the Corn Belt region (Donner and Scavia, 2007; Scavia and Donnelly, 2007).

\subsection{Present and future human impacts}

As the research into the causes and possible solutions to the "Dead Zone" progresses, so too does the expansion of corn production in the Midwest in response to increased demands for ethanol, further complicating the problem (Donner and Kucharik, 2008; Martin, 2011). In an effort to address these feedbacks and improve water quality, while at the same time meeting the new fuel demands, large-scale planting of highyielding perennial biomass crops is being investigated. Since these crops have lower fertilizer requirements than the corn currently grown in this region for biofuels, this would effectively reduce the amount of nitrate exported to the Gulf of 
Mexico. However, this could also be potentially detrimental to both human and environmental streamflow users because some of these grasses require more water than do current crops. The lowest natural flows in this shallow groundwaterdependent region occur soon after the peak of the growing season; thus, in an effort to solve the water quality problem a water quantity problem may be created. Therefore, for largescale biomass crop production to be sustainable, these tradeoffs between water quality and water quantity must be fully understood. To this end, two watersheds, representative of typical Corn Belt catchments, were chosen for detailed analysis of their hydrologic response to human and natural impacts. We mainly focus our analysis on a few hydrologic signatures: the regime curve, flow duration curve, and the characteristics of a low flow analysis centered on the summer low flow season. The aim of this paper, then, is to take what can be learned from the long history of change and response to change in these watersheds, as evidenced in the streamflow of 1990-2011, and apply it toward predictions of future behavior. We expect that a comparative analysis of hydrologic signatures will provide insights into why these watersheds respond as they do and thus enable better predictions of how these watersheds may respond to unknown changes in the future.

\section{Methods}

\subsection{Data description}

Data used in the following analyses, including those used to create the land cover maps previously presented in Fig. 1 are summarized in Table 1. All spatial data presented in this paper are available as part of much larger data sets that were then clipped to the boundaries of the study area in order to better compare in detail the characteristics of the two selected watersheds.

\subsection{Study area - watershed spatial characteristics}

The study area consists of two watersheds in central IL (Fig. 2). To the north is the $14000 \mathrm{~km}^{2}$ Sangamon River watershed, a tributary of the Illinois River which itself is a tributary of the Mississippi River. To the south is the Kaskaskia River watershed, a roughly $15000 \mathrm{~km}^{2}$ tributary of the Mississippi River. Although each watershed consists of four main hydrologic units (HUCs), the hydrologic connectivity differs between them. The Sangamon watershed consists of an upper and lower main-stem and two hydrologically separate tributaries - Salt Creek in the north and South Fork in the south, with confluences in the lower Sangamon. The Kaskaskia watershed consists of an upper, middle, and lower main-stem and one large tributary, Shoal Creek. There are three in-line reservoirs of note in these watersheds, each with a different purpose and release rules. In Sangamon, Lake Decatur has provided water supply for the city of Decatur since its construction in 1922; in Kaskaskia, the more recent Lake Shelbyville in the north mainly provides recreation, while Lake Carlyle in the south provides water supply, recreation, and flood control for both the Kaskaskia and Mississippi Rivers. Locations of these reservoirs as well as the main-stem and tributary stream gauge locations are shown in Fig. 2. On average, the region receives about $1000 \mathrm{~mm}$ of rain annually, although there can be a great deal of spatial variability due to a higher frequency of high-intensity convective rainfall events that cover localized areas compared to less intense frontal events that cover large areas. Precipitation is slightly seasonal here, with the spring months being wetter on average than the rest of the year, followed by drier late summer months that closely follow the period of peak evaporative demand.

The legacy of the geologic history of these two watersheds manifests in their topography and soils, as well as the vegetation that has co-evolved with both, under influence of the climate. The relatively flat topography (Fig. 3a) is a result of glaciation, and in the case of the Sangamon watershed, repeated glaciation. There is more topographical relief in Kaskaskia compared to Sangamon; in Sangamon, a gentle ridge divides the watershed about midway downstream, separating an extensive, flat upland region from the mostly flat lowland region. The same ridge that divides the Sangamon watershed extends into Kaskaskia, separating the upper portion, which shares soil, vegetation, and drainage characteristics with Sangamon, from the rest of the Kaskaskia watershed, which is marked by gentle slopes to deeper valley bottoms. These valley slopes provide enough topographical relief that the middle and lower Kaskaskia were more welldrained naturally (Prince, 1997) than the Sangamon and the upper Kaskaskia.

The geologic history also had significant implications on the soils and vegetation that co-evolved in these two watersheds: to the north, more recently glaciated portions of both watersheds developed mollisols rich in organic matter under dense grassland, while to the south, weathering produced alfisols that developed mainly under forest vegetation (Fig. 3b). The pre-settlement land cover (Fig. 1a) illustrates this well Sangamon and upper Kaskaskia were dominated by prairie grassland vegetation, while the rest of Kaskaskia was mostly forest vegetation. Estimating from the IL Natural History Survey data set, the Sangamon was roughly $90 \%$ prairie while the Kaskaskia was about $85 \%$ forest. It is interesting to note that present-day land cover in Sangamon and upper Kaskaskia still follows these proportions, although the prairie grasses have been replaced for the most part by row crop agriculture. Even though much of the forest in Kaskaskia is gone, pasture and forest vegetation together comprise about $30 \%$ of the watershed, compared to only $10 \%$ in Sangamon.

Both the Sangamon and upper Kaskaskia require extensive tile drainage (Fig. 3c) for crops to be successfully grown, due in part to a hardpan subsoil layer combined with lack of a natural surface drainage network resulting from their flat, 
Table 1. Description of and sources for all data used in this study.

\begin{tabular}{llc}
\hline Data Description & & Data Source \\
\hline Land cover map, 1800s, IL & IL Natural History Survey, & http://wwx.inhs.illinois.edu/resources/gis/glo/ \\
& Prairie Research Institute (contact for data file) & \\
$30 \mathrm{~m}$ land cover, 2001 & USGS National Map & $\mathrm{http} / / /$ nationalmap.gov/viewer.html \\
$30 \mathrm{~m}$ digital elevation map (DEM) & USDA NRCS & $\mathrm{http}: / /$ soildatamart.nrcs.usda.gov/USDGSM.aspx \\
STATSGO soils map, by state & World Resources Institute (WRI) & $\mathrm{http} / / / \mathrm{pdf}$. wri.org/assessing_farm_drainage.pdf \\
Estimates of percent tile drainage, by county & http://maps.waterdata.usgs.gov/mapper/index.html \\
Daily streamflow & USGS NWIS & $\mathrm{http} / / /$ prism.nacse.org/ \\
Annual and monthly precipitation & PRISM Climate Group & \\
\hline
\end{tabular}

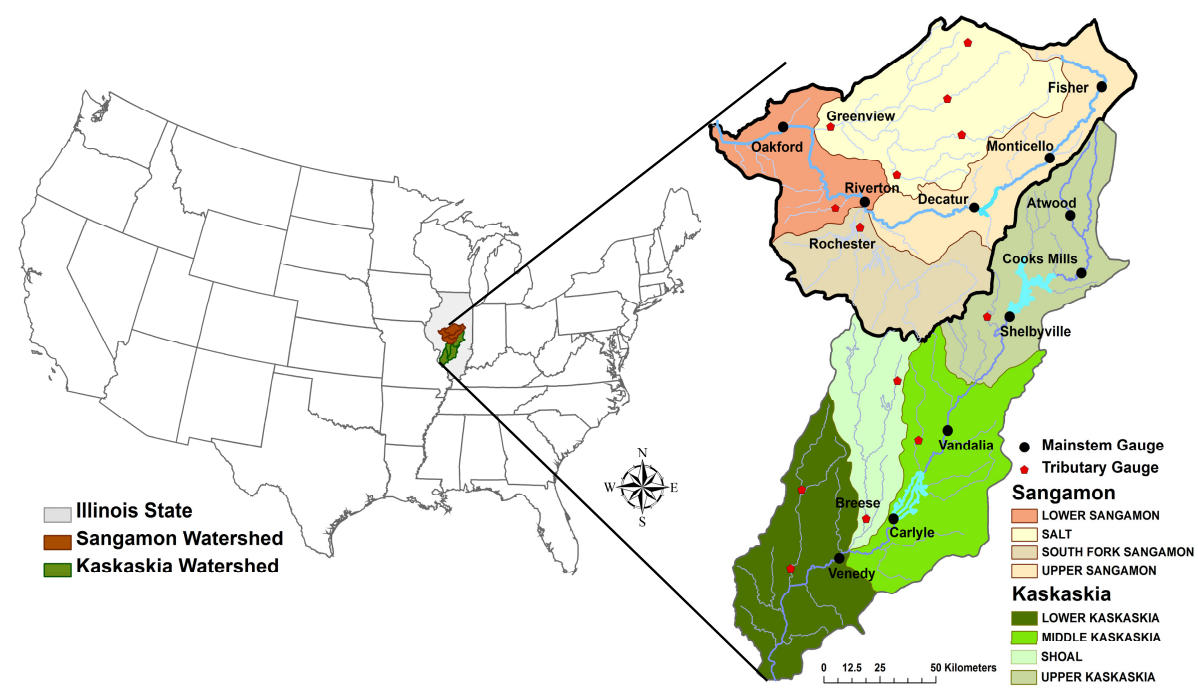

Fig. 2. Locator map for the Sangamon and Kaskaskia watersheds with gauge site and stream details.

upland topography. In the southern portions of the Kaskaskia watershed, installation of tile drainage is impeded by a shallow fragipan layer; however, this is not a problem for agriculture since waterlogging is less common here, due in large part to the higher slopes the landscape here tends to have and which may also explain why deep-rooted forest vegetation was able to become established here.

\subsection{Streamflow analyses}

For the comparative analysis of streamflow time-series data, observed daily streamflow data for 24 USGS gauges, 12 each in both Sangamon and Kaskaskia watersheds, was obtained for a $22 \mathrm{yr}$ period from 1990 through 2011. This time period was chosen to reflect the current condition of the watersheds, which would include the cumulative effects of past land use/land cover and climate changes. Unfortunately, very few gauges have sufficient historical data to perform the same analyses for the 1940 s or earlier as a comparison. Of the 12 gauges chosen for each watershed, 5 were located on the main-stem of Sangamon and 6 on the main-stem of Kaskaskia, with the remaining gauge locations distributed among the tributary streams in each watershed (Fig. 2).
Gauges were chosen primarily for length of record; there are many more gauges in these watersheds that have been installed recently, but their period of record is too short for meaningful analysis. To aid comparison between subwatersheds of differing sizes, the daily instantaneous flow rate (cfs) from the gauge records was converted to daily volume $\left(\mathrm{m}^{3}\right.$ day $\left.^{-1}\right)$ and then scaled by drainage area $\left(\mathrm{m}^{2}\right)$ and converted to $\mathrm{mm}$ to give water yield.

Hydrologic signatures at three timescales were then calculated from the daily record. The inter-annual variability signature sorts annual total streamflow from highest to lowest exceedance, with a flat slope to the plot signifying low year-to-year variability in streamflow. The regime curve (RC) plots the monthly average streamflow over the year and shows the seasonal streamflow patterns within the year. Lastly, the flow duration curve (FDC) plots daily streamflow magnitude (on a log scale) as a function of the percent of time it is exceeded. The FDC can be divided into 3 sections, with the upper third corresponding to flood events and the fast flow response of a catchment, the middle third to the slow flow response of the catchment and its regime curve, and the lower third the low flow response (Yokoo and Sivapalan, 2011). While the upper third of the FDC is mainly related to 

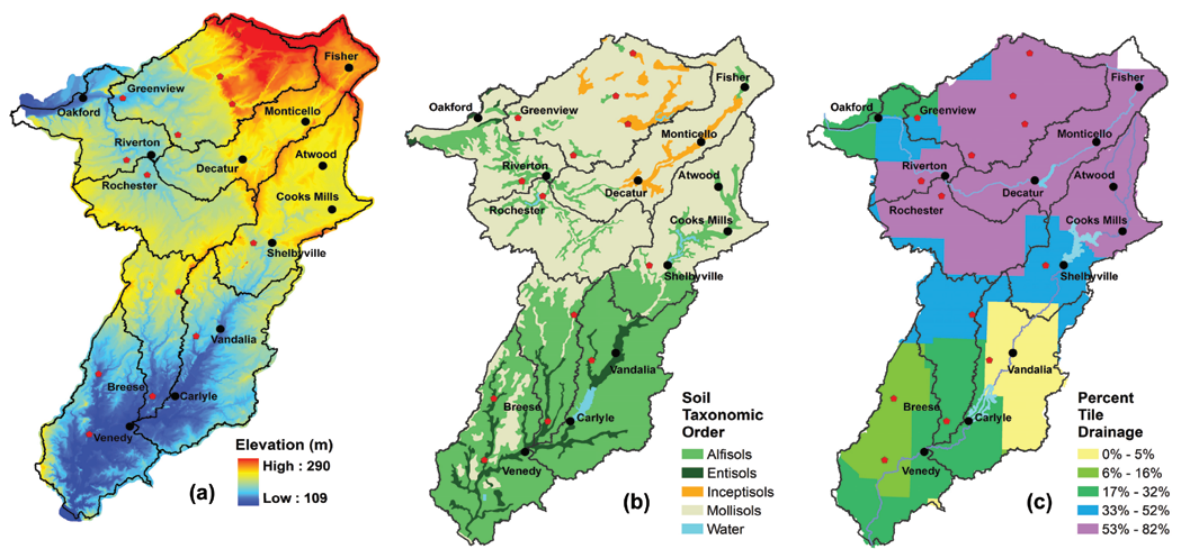

Fig. 3. USGS topography (a), STATSGO soil taxonomy (b), and WRI estimates of percent tile drainage by county (c).

precipitation intensity, the lower third is more related to properties of the catchment itself (Yaeger et al., 2012). The lowest streamflows occur in the late summer to early fall when evaporative demand still exceeds precipitation but when crop vegetation (although not forest vegetation) is beginning to die off. With the proposed land use changes affecting the length of the growing season and thus the amount of ET during this time, the present study will specifically focus on the low flows.

Because the historical analysis of the region indicated that baseflow had increased over time due to changes in crop rotations and expanded tile drainage, the baseflow index (BI), defined for a given time period as the ratio of mean annual slow flow to mean annual total flow, was also calculated. Separation of daily streamflow at each gauge into the fast and slow components was accomplished with a simple one-parameter low-pass filter as described in Ye et al. (2012).

Examination of the monthly regime curve showed that, on average, summer flows are smaller than winter flows; thus only the summer low flow period, defined here as the days of 15 July through 15 November of each year in the period of record, was chosen for the low flow analysis. The streamflow threshold method was chosen to determine streamflow drought periods (Yevjevich, 1967; Zelenhasić and Salvai, 1987); at each gauge the area-averaged streamflow (water yield) corresponding to both the 90th and 95th percentiles on the flow duration curve was used as the threshold (Zelenhasić and Salvai, 1987). After the initial analysis, it was determined that the 95th percentile flows in this region were too small to produce meaningful results; thereafter, only the flow corresponding 90th percentile $\left(Q_{90}\right)$ was used, and these results are presented later in this paper. A streamflow deficit was determined to occur if the daily flow $\left(Q_{\mathrm{d}}\right)$ during the summer low flow period was less than the threshold flow (Fig. 4). Since daily area-averaged flow was used, the total deficit volume for a given deficit period can be defined as

$q=\sum_{d=1}^{t_{r}}\left(Q_{90}-Q_{\mathrm{d}}\right)$

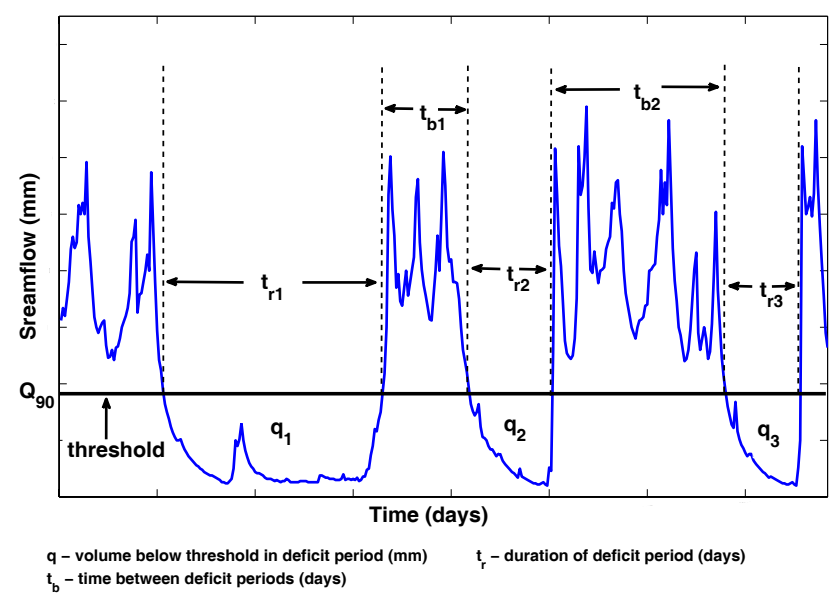

Fig. 4. Definition of deficit, deficit period, and occurrence interval used in low flow analysis.

where $d=1$ is the first day where $Q_{\mathrm{d}}<Q_{90}, t_{r}$ is the total duration (days), and $q$ is the total volume $(\mathrm{mm})$ for that duration period. If there was more than one deficit period in a low flow season, the time between deficit periods $t_{b}$ (days) was also recorded; if only one deficit period occurred in a year, $t_{b}$ was recorded as 0 . This analysis was repeated for each year in the period of record. In some cases, a day or two where $Q_{\mathrm{d}}>Q_{90}$ separated two longer deficit periods. According to Zelenhasić and Salvai (1987), these two deficit periods are likely to be related, and thus should be considered one long deficit period. To prevent related deficit periods from being counted as separate events, a threshold $t_{b}$ of 3 days was chosen based on examination of the low flow behavior of a few gauges so that in a given year, consecutive deficit periods having fewer than 3 days between them were merged into one deficit period. Lastly, the mean and standard deviation were calculated for $q, t_{r}$, and $t_{b}$ to give an overall picture of the low flow response from these watersheds. Even after normalizing by drainage area, there was sufficient variability in the threshold flows that the average relative deficits (RD), 
defined here as the ratio of the average deficits to their respective $Q_{90}$, were also calculated (Hisdal and Tallaksen, 2003).

Lastly, to gain a quantitative idea of the spatial and temporal variability of precipitation in this region, 9 points were selected covering the spatial extents of the two watersheds; from west to east, 3 points were chosen across the northernmost latitude, 3 across the southern, and 3 across the divide between the two watersheds. Annual and monthly precipitation data was obtained from the PRISM data set (Table 1) at each of these locations and was used to calculate both the inter-annual variability and monthly regime curves for the precipitation.

\section{Results}

\subsection{Hydrologic signatures}

The inter-annual variability signature of the streamflow of these watersheds (Fig. 6) shows that there is some variability in total streamflow between years, especially for the driest years, but less so in Kaskaskia. The differences in annual streamflow between the two watersheds can be explained in part by the spatial variability in precipitation described in Sect. 2.2 and which is shown in Fig. 5, as well as the catchment response to it. Slower-draining catchments, such as those in middle and lower Kaskaskia, tend to even out this spatial variability in precipitation, but the extensive tile drainage in the Sangamon mitigates this filtering effect. In addition to this localized variability, there is also a regional north-south gradient to the annual precipitation, with the southern portions of Kaskaskia on average receiving more rainfall annually than the northern parts of Sangamon (Fig. 5). Of interest is Sugar Creek in the Sangamon (Fig. 6, light blue dashed line), a small $\left(89 \mathrm{~km}^{2}\right)$ headwater stream in the upper Salt Creek HUC. Why such a small stream experiences such high runoff is not explained by climate variability alone. This represents another human impact signature: the local municipality discharges treated wastewater, the source of which is likely groundwater or water supply from a lake outside the watershed, into Sugar Creek, thus artificially inflating the hydrograph.

The regional variability in precipitation also manifests at the monthly scale (Fig. 7) with the north-south gradient evident in the winter and early spring, but not so in summer and early autumn. For the seasonal pattern of monthly average streamflow, aside from Sugar Creek, there is very little variation between sub-catchments in the Sangamon watershed, even immediately downstream of Lake Decatur (Fig. 8). Winter flows are larger on average than summer, and the flood peaks all occur in May, coinciding with peak rainfall for the most part and the very beginning of the growing season. There is a smaller, secondary peak in March, most likely due to spring rainfall and snowmelt. From May to June there is only a slight decline in monthly flow; this is because the

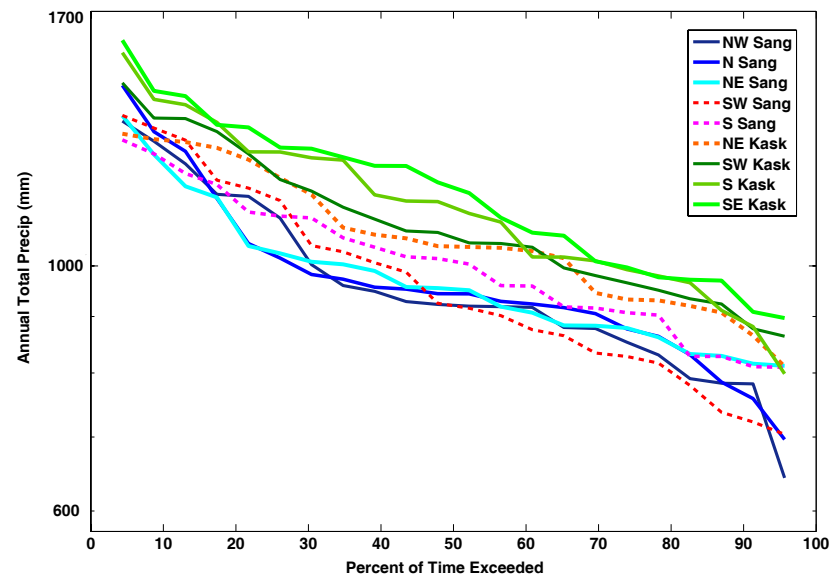

Fig. 5. Precipitation inter-annual variability for both watersheds for 1990-2011.

crops are not yet at peak water usage and the tile drains move excess infiltration (once it reaches them) quickly to drainage ditches and streams. The steepest decline happens later from June to July, when crop ET is at its peak. In contrast, there is much more variability in the seasonal streamflow patterns for Kaskaskia. The influence of the two reservoirs in the Kaskaskia watershed can clearly be seen in the Shelbyville, Vandalia, Carlyle, and Venedy regime curves: winter flow is increased (to lower the water level in the reservoir), and the May flood peak is greatly reduced, with the excess water slowly released so that the lowest monthly flow (for this time period) is shifted from August to September and October. The flow regimes for the rest of the Kaskaskia gauges, located on uncontrolled reaches, show a general seasonal pattern similar to that in Sangamon, although a closer look reveals an interesting exception. The regime curves for Kaskaskia tributary streams (Fig. 8, dashed lines) show a sharp, almost linear decline from May to July, while those for Atwood and Cooks Mills, two main-stem gauges located above Lake Shelbyville in an area where land use, soil type, and tile drainage are similar to those in Sangamon, show the same small decline from May to June and sharp decline from June to July that was seen in Sangamon RCs. Thus, three distinct flow regime patterns are discernable in Kaskaskia: reservoir-dominated, row-cropped and tiled-drained, and less artificially drained with more heterogeneous land cover.

For the monthly RC, the streamflow patterns for the Sangamon were much less variable than those for Kaskaskia. For the daily FDC, however, the reverse is true, especially for the low flows (Fig. 9). There is more variability in the lower tail (66\%-100\% exceedance) in the Sangamon Basin compared to the Kaskaskia. Another human impact on streamflow can be seen at the Decatur gauge. Lake Decatur supplies water to both the City of Decatur and a large ethanol refinery nearby. The Decatur gauge shows no flow almost $5 \%$ of the time, while upstream (Monticello) and downstream 

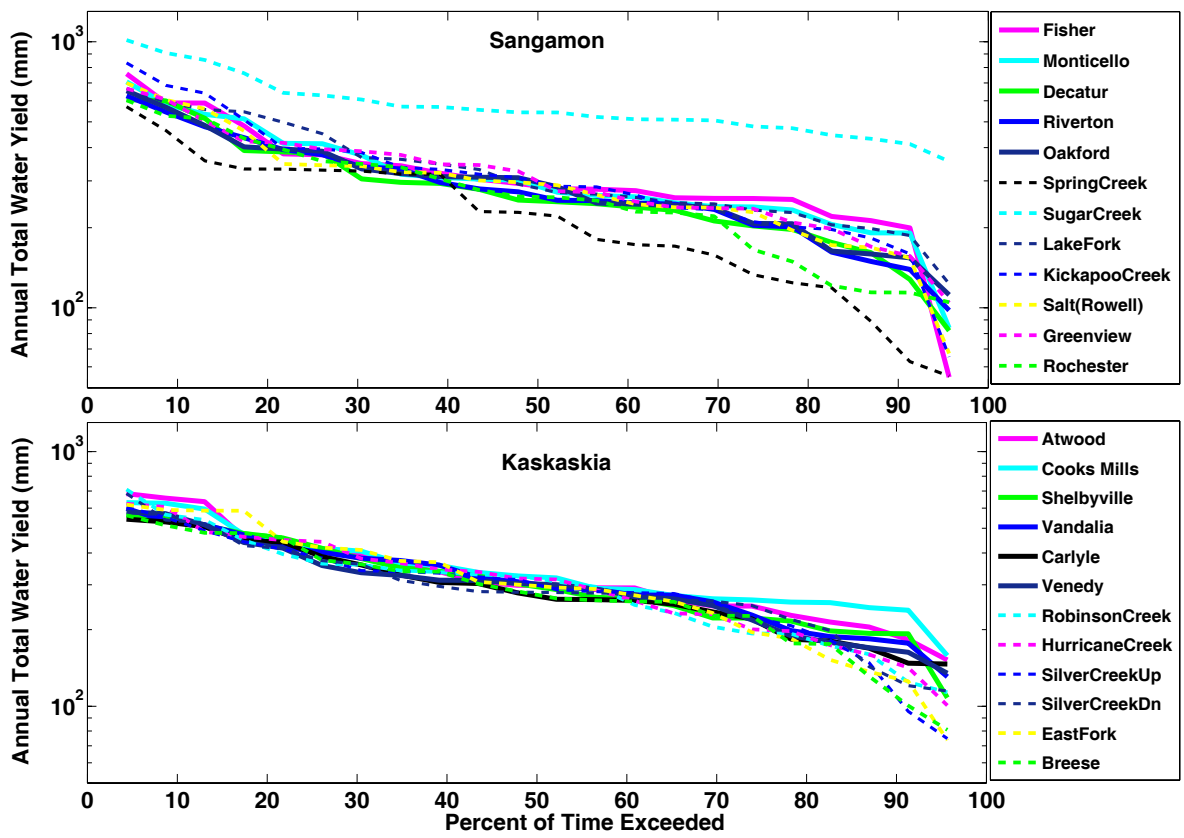

Fig. 6. Streamflow inter-annual variability for both watersheds for 1990-2011. Note that main-stem gauges are shown as solid lines and tributary gauges are shown as dashed lines.

(Riverton) do not. This is likely due to the demand plus evaporation in summer being greater than the inflow from upstream. Downstream of the Decatur gauge is the wastewater discharge point for the city; thus the Riverton gauge further downstream does not manifest the expected decrease in flow. The middle limb of the FDC, which represents the average, regime flows at each gauge, shows little variability within the Sangamon watershed, just as was seen in the RCs (Fig. 8). Also as seen in the RCs, the reservoirs' influence is clearly evident in the Kaskaskia FDCs as increased variability in the upper portion of the FDC (high flows reduced on controlled reaches) and convex curvature to the middle limb of the FDC (increasing mean flows of the same reaches). Of note is the much smaller variability in the low flows in Kaskaskia compared to Sangamon, which could be due to there being fewer drainage tiles in Kaskaskia. In that sense, streamflow in Kaskaskia would then be more "filtered" than streamflow in Sangamon; without tile drainage, inputs are retained longer and thus the output is more processed by the catchment. It is also interesting to observe that the gauges downstream of Sugar Creek (Greenview and Oakford) have consistently large low flows, even at $95 \%$ exceedance; this is likely due to the effects of the artificially high flows in Sugar Creek propagating downstream. The flat slope of some of the low flow tails of the Sangamon FDCs would also seem to indicate increased baseflow compared to Kaskaskia.

In general, as drainage area and streamflow increases, heterogeneity decreases, and this pattern can be seen, for Kaskaskia at least, even for the lower portion of the FDC (here the $65 \%-95 \%$ exceedance). When low flow FDC

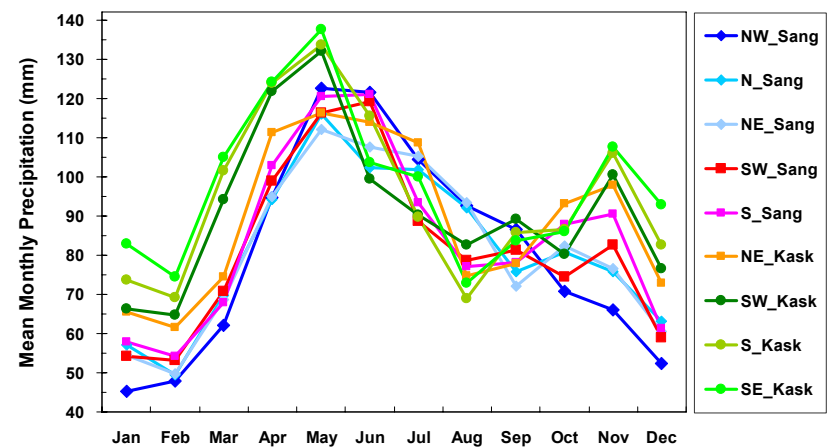

Fig. 7. Monthly precipitation regime curves for both watersheds for 1990-2011.

quantiles of daily water yield for both watersheds are plotted against their respective drainage areas, there is less of a trend in the Sangamon quantiles compared to Kaskaskia (Fig. 10). An interesting outlier in this figure, shown in the circled portion of Fig. 10a, is the Sugar Creek catchment, where streamflow has been artificially increased due to discharge of treated wastewater. Since there is less variability in human water use, overall streamflow variability decreases; this was also seen previously as a much flatter FDC compared to other streams in the watershed (Fig. 9). Furthermore, based on regression analysis for $Q_{65}$ (Fig. 10, brown lines) and $Q_{95}$ (Fig. 10, blue lines), we expect the magnitude of water yield to increase with an increase in drainage area; however, two mid-size subwatersheds (Decatur and Rochester) have water yield magnitudes similar to a subwatershed an 


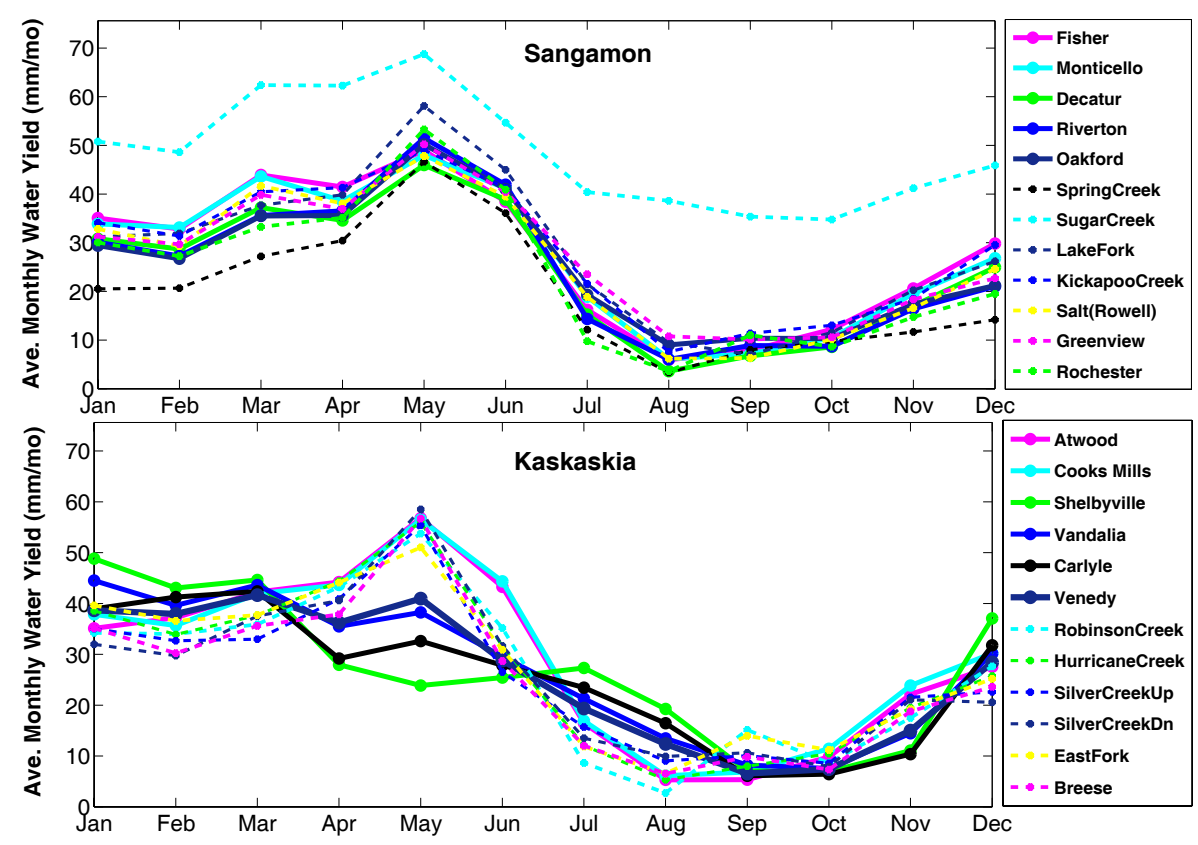

Fig. 8. Monthly regime curves for both watersheds for 1990-2011. Note that Main-stem gauges are shown as solid lines and tributary gauges are shown as dashed lines.
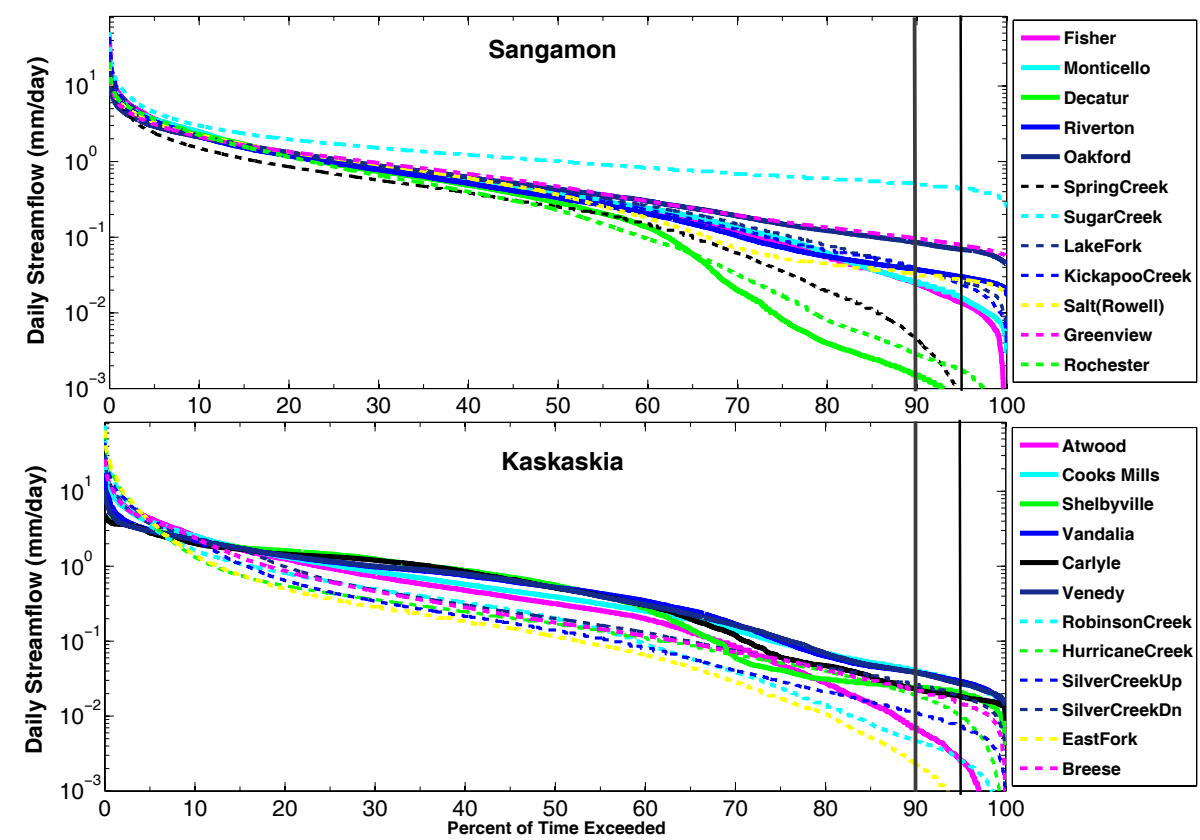

Fig. 9. Flow duration curves of both watersheds for the period 1990-2011. Note that Main-stem gauges are shown as solid lines and tributary gauges are shown as dashed lines.

order of magnitude smaller in size (Spring Creek, in lower Sangamon). From the FDC, we see that all three of these subwatersheds occasionally experience zero daily flow (Fig. 9). For Spring Creek, this is likely due to the small drainage area $\left(<100 \mathrm{~km}^{2}\right)$; for Decatur and Rochester, this is more likely due to municipal and industrial water supply diversions that bypass the flow gage, but the diverted water remains within the Sangamon Basin and thus does not impact downstream gages. In Kaskaskia, however, there appears to be a more structured, nonlinear relationship with drainage area for the smallest flows, becoming more linear as drainage area increases. For both watersheds, smaller drainage areas with 

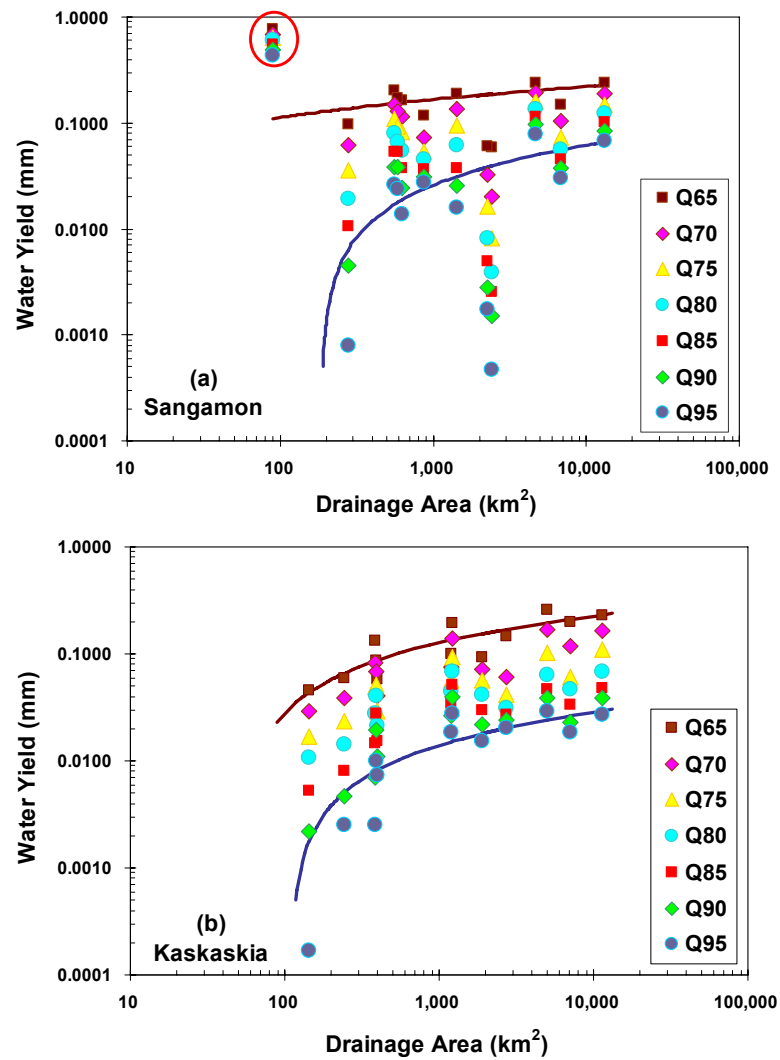

Fig. 10. Scaling of the lower limb of the FDC with drainage area in (a) Sangamon and (b) Kaskaskia. Note that the circled area in (a) is the Sugar Creek catchment.

extensive tile drainage tended to experience lower extreme low flows than did non-tile-drained areas; as drainage area increases this effect becomes less clear due to an increasing combination of effects of other catchment modifications.

In summary, there is some variability in streamflow, even at the annual scale, most noticeable in dry years, and likely a catchment response to spatial variability in precipitation. At the monthly scale, the high level of tile drainage and similarity in land use, and lack of controlled reservoirs in the Sangamon watershed results in most of the gauges responding in a similar fashion throughout the year. Kaskaskia on the other hand, shows a much more heterogeneous seasonal response, due to the presence of two large controlled dams, a relative lack of tile drainage, and more heterogeneous land cover. Finally, at the daily scale, the catchments in Kaskaskia produce much more uniform FDC low flow tails than do the catchments in Sangamon. Although the FDC has limitations - the linear time element has been removed - the higher variability seen in the low flow tails has important implications for the proposed biofuel crop changes, as we expect that the major impacts of this land use change will be felt here. To understand what these impacts might be, we begin with a low flow analysis of the late summer and early fall streamflow period.

\subsection{Low flow analysis}

Overall, average deficit volumes in the Kaskaskia watershed are fairly small $(<0.2 \mathrm{~mm})$, with an average time between, in most places, of about a week, but varied in their average duration. However, some of the threshold flows were also very small, particularly those of headwater streams; as a consequence of the very small denominator, Kaskaskia showed the largest average RD of either watershed (10-13 times the $Q_{90}$ threshold). For the rest of the watershed, the average RD of the main-stem reaches was, on average, 2.5 to 4.5 times the threshold flow, while the RD of tributary reaches was, with the exception of the southernmost gauge, a little higher (Fig. 11a). Like Kaskaskia, the headwater main-stem reach in Sangamon showed a large average RD ( 8 times the threshold), but for the rest of the Sangamon watershed there does not appear to be a strong spatial pattern to the average RD as there was in Kaskaskia. Here, some tributary reaches experienced larger average RD (7.0-9.5 times than the threshold) while others did not, and aside from Riverton, the Sangamon main-stem RD were larger than those in Kaskaskia. There was also more spatial variability in the average magnitudes of $t_{r}$ and $t_{b}$ in the Sangamon watershed compared to Kaskaskia; in Sangamon, mean deficit durations ranged from the highest to the lowest values (6-30 days), while in Kaskaskia the range was much smaller (10-18 days) (Fig. 11b). The same was true for the time between deficit periods; in Kaskaskia, $t_{b}$ varied between 4 to 8 days, while in Sangamon the range was 2 to 11 days (Fig. 11c). For the study period, on average, deficit periods were shorter and more frequent in Sangamon than in Kaskaskia (Fig. 12).

Figure 13 presents the low flow analysis in terms of scaling with drainage area. Again, there is more scatter in Sangamon compared to Kaskaskia, although both watersheds show a general trend of decreasing average RD with increasing drainage area. This pattern of higher variability for Sangamon compared to Kaskaskia also held for mean deficit duration and time between deficits when plotted against drainage area (not shown for sake of brevity). It should be noted that the one outlier in Fig. 13 is the Sugar Creek gauge, where wastewater discharge from sources outside the basin have artificially increased the streamflow.

The baseflow analysis yielded interesting results. Overall, BI for the Sangamon gauges ranged from 0.5 to 0.69 , with the exception of two downstream gauges, Greenview at the outlet of the Salt tributary and Oakford, the far downstream main-stem gauge, both of which are downstream of the Sugar Creek gauge as well as being channelized and straightened. Three different groupings can be seen in the Kaskaskia BI values (Table 2), which correspond to the three flow regime patterns seen in the regime curves (Fig. 6). The less tiledrained sub-watersheds in Kaskaskia with more heterogeneous land cover showed $\mathrm{BI}<0.5$, while the two gauges in the tile-drained, row-cropped upper Kaskaskia region had BI values similar to those in Sangamon. All main-stem 

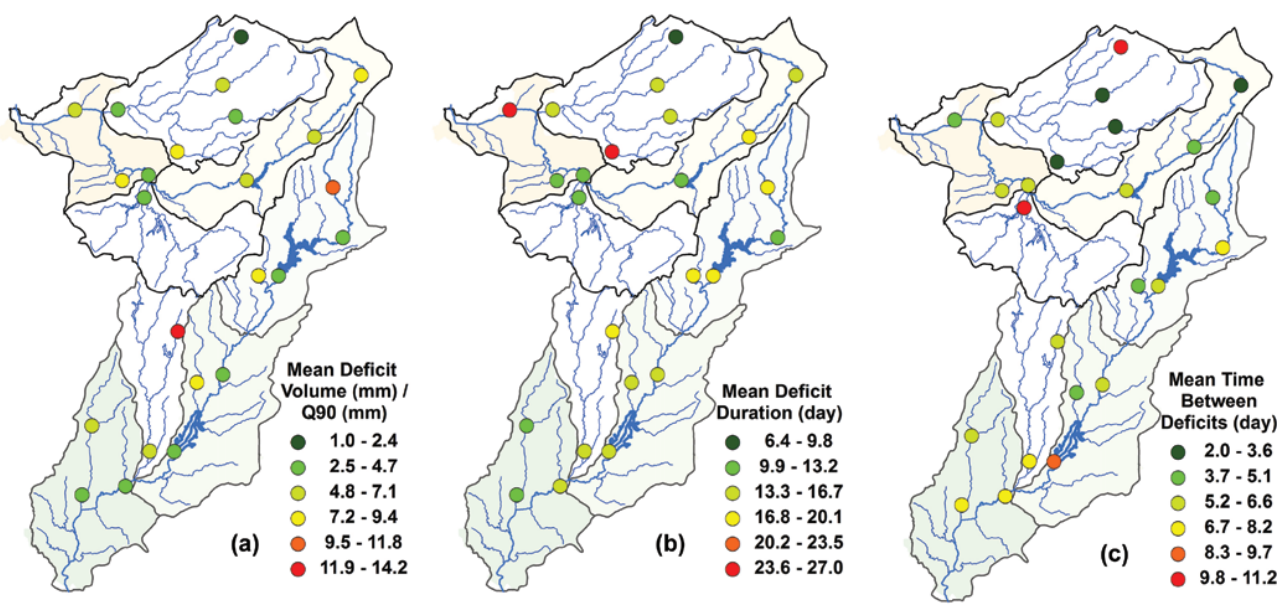

Fig. 11. Relative deficit (a), mean deficit duration (b), and average time between deficits (c) for both watersheds.

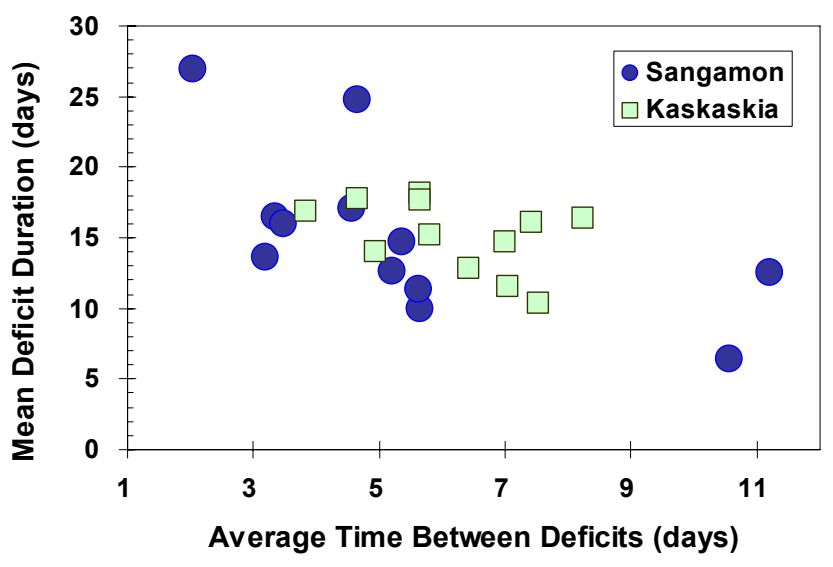

Fig. 12. Average frequency vs. duration of deficit periods from 1990-2011.

gauges below the reservoirs in Kaskaskia, as well as the two downstream gauges in Sangamon mentioned above, showed $\mathrm{BI} \geq 0.7$. Channelization of river reaches increases baseflow by increasing the area in contact with deeper groundwater sources; flood control reservoirs increase baseflow by releasing excess storage during natural low flow periods in order to ensure sufficient storage for the high flow periods. Lake Decatur is not a flood control reservoir, and so does not show this release pattern.

\section{Discussion}

\subsection{Legacies of the past manifested in current hydrologic responses}

The case study catchments reflect in many ways the legacies of their pasts. The glacial histories of each watershed influenced the soils and vegetation that co-evolved, and these,

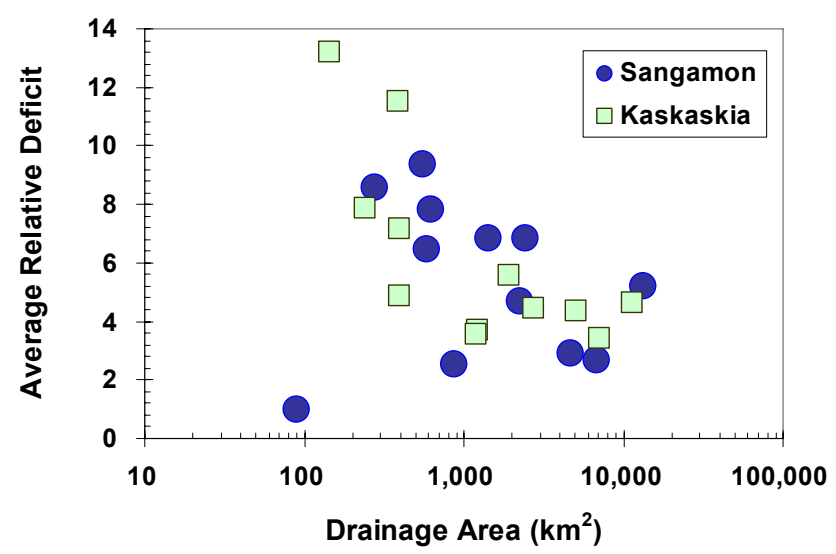

Fig. 13. Scaling of relative deficit with drainage area.

combined with the topographical differences between the two watersheds influenced the amount and type of drainage European settlers needed to implement to prepare the land for agriculture. In Sangamon and upper Kaskaskia, a shallow groundwater table combined with a flat topography, required extensive surface and subsurface drainage to prevent waterlogging and allow crops to flourish. In the past, this region was predominately wet prairie; today it is predominately annual row crop agriculture. This has manifested in the catchment response as a homogenous seasonal flow regime, increased variability in the low flows, and an higher BI. The rest of the Kaskaskia watershed has very little tile drainage for a combination of reasons, all of which are linked to historical impacts. The glacial legacy of this region resulted in greater topographical relief so that it is more well-drained naturally, and flatter, waterlogged portions are sufficiently improved with only surface drainage modifications. Furthermore, the shallow fragipan layer underlying much of the watershed makes extensive tile drainage infeasible. Historically, this region was predominately forested, and although 
Table 2. Baseflow Index values for 1990-2011 and associated catchment features for (a) Sangamon and (b) Kaskaskia.

\begin{tabular}{lrllrl}
\hline (a) Sangamon & BI & Feature & (b) Kaskaskia & BI & Feature \\
\hline Fisher & 0.58 & & Atwood & 0.56 & Tiled, \\
Monticello & 0.61 & & CooksMills & 0.59 & row cropped \\
\cline { 4 - 6 } Decatur & 0.53 & & Shelbyville & 0.75 & \\
Riverton & 0.63 & & Vandalia & 0.71 & Reservoirs or \\
SpringCreek & 0.58 & Tiled, & Carlyle & 0.78 & channelized \\
SugarCreek & 0.65 & row cropped & Venedy & 0.75 & \\
\cline { 4 - 6 } LakeFork & 0.63 & & RobinsonCreek & 0.46 & \\
KickapooCreek & 0.60 & & HurricaneCreek & 0.33 & Less tiled, \\
Rochester & 0.59 & & SilverCreekUp & 0.36 & row cropped, \\
Salt_Rowell & 0.67 & & SilverCreekDn & 0.44 & pasture, forest \\
\cline { 5 - 6 } Oakford & 0.71 & Reservoirs or & EastFork & 0.30 & \\
Greenview & 0.70 & channelized & Breese & 0.47 & \\
\hline
\end{tabular}

the present-day land cover is predominately annual row crop agriculture, there is also a large amount of pasture land and forest as well. In addition, large flood control reservoirs constructed in Kaskaskia to regulate streamflow also provide a water quality benefit; because of the increased residence times, the total mass output of nitrate-N from Kaskaskia is less than that from Sangamon. These differences in land cover, subsurface drainage, and reservoir operation have all manifested in the catchment response as three distinct groupings in the seasonal flow regime, and these patterns are also reflected in the BI.

The overall effect of tile drainage on the hydrologic response is one of introducing a new threshold. Infiltrated precipitation reaches the low-permeability sub-soils and begins to saturate the soil column until it reaches the depth of the tile drains, which then provide a preferential flow pathway toward the surface drainage network. This reduces the time that the soil layer above the tile drain is waterlogged and thus damaging to crop roots. It also limits replenishment of root zone soil moisture from the saturated layers below. Thus, in the summer growing season, when there is less precipitation and evaporative demand is greatest, the major source of soil moisture is from throughfall. During this period, smaller ditches and streams dry up as the soil does, while larger streams are fed by baseflow from deeper soil moisture storage. This can be seen in the summer low flow period in the RC (Fig. 8), and in the FDC (Fig. 9) of smaller tributary streams where flow is not exceeded $100 \%$ of the time. The low flow analysis revealed that on average, the Sangamon watershed experienced shorter but more frequent streamflow deficit periods than did Kaskaskia during 19902011. However, there was also more variability associated with deficit periods in Sangamon, compared to Kaskaskia, due in part to drainage effects on the catchments' response to localized spatial variability in precipitation. A recent study of hydrologic drought by Van Lanen et al. (2013) found that groundwater, as manifest in catchment response times, is a more important control on drought duration and deficit magnitude than either climate or soil type, and that fast catchment response times increased the frequency of deficit periods. All these findings could have important implications for the sustainable large-scale planting of cellulosic biofuel energy crops such as Miscanthus in this region.

\subsection{Implications for biofuels land use change}

As mentioned previously in Sect. 1, Miscanthus is a perennial grass, which means it is not planted according to an annual timetable, as corn and soybeans are, but emerges from winter dormancy when soil and air temperatures are sufficiently warm. This typically occurs around the beginning of April, as opposed to corn and soybeans which are usually planted starting in mid-April and starting in early May, respectively. At the end of the growing season, ET of corn and soybeans declines and ends a few weeks before harvest, which usually occurs at the beginning of October, but Miscanthus continues to transpire until the first frosts, usually in November (Schilling et al., 2008; McIsaac et al., 2010; Le et al., 2011), so that its growing season is two months or more longer than the current row crop annuals. In addition, the canopy of Miscanthus is much more dense than that of corn or soybeans, with a maximum leaf area index (LAI) of up to 10 compared to 7 for soybeans and 5.5 for corn (Heaton et al., 2008; Le et al., 2011) which would also intercept more water than the annual crops, thus reducing throughfall in addition to drying the soil profile earlier in the year (McIsaac et al., 2010). In a tiledrained watershed, this could mean that the local streams become baseflow-dependent earlier in the year than under row crops, and, in dry years especially, experience larger and/or longer deficit periods during the summer low flow season. On the other hand, the greatly reduced fertilizer requirements of Miscanthus would mean a significant decrease in nitrate export from tile-drained watersheds. 
The increased fine-scale heterogeneity brought to light by the analysis of recent streamflow data is a complicating factor when predicting how these catchments would respond to large-scale planting of Miscanthus, since knowledge from one location within the watershed cannot be directly transferred to another, similar location in the same watershed. When combined with the inherent spatial variability of the precipitation inputs, we see there are limitations to what can be learned from observed data. However, much modeling work has been done to try to predict the impacts of this new crop on the hydrology of the region, both at the watershed and at river basin scales. Using a dynamic global vegetation model to simulate crop ET in the Midwestern US, Vanloocke et al. (2010) found statistically significant increases in annual ET and a corresponding decrease in hillslope drainage even for moderate fractions of land planted with Miscanthus. The impacts of this change, however, varied with location; where water resources were already stressed, largescale planting of Miscanthus tended to worsen conditions. More recently, a smaller scale study of the Iowa River basin (Wu and Liu, 2012) using the watershed hydrologic model SWAT obtained similar hydrologic results. A second largescale study used the SWAT model to examine the effects of planting switchgrass, another proposed biofuels crop, in the upper Mississippi River basin (Wu et al., 2012). Similar to what has been found for Miscanthus, converting land to switchgrass reduced nitrogen export and soil erosion but also increased ET and decreased the baseflow component of streamflow. Each of these studies covered similar regions of the US where there is extensive tile drainage, and all shared a common result that an increase in fraction of land covered by Miscanthus led to an increase in annual ET and a corresponding decrease in hillslope drainage to streams. The hydrologic impacts, however, varied with the scale of the study, the fraction of Miscanthus investigated, the crop that was replaced by Miscanthus, and, for the larger-scale studies, the location within the watershed as well.

The threshold effect of the tile drains coupled with the switch from perennial and sod vegetation to intensive annual row crop agriculture led to an overall decrease in ET and an increase in baseflow. Large-scale planting of Miscanthus, a perennial grass, would have the opposite effect, dependent on the location and amount planted, and current hydrologic conditions, creating a kind of biofuels threshold effect. As the fraction of Miscanthus in a watershed increases toward this threshold of sustainability the effects will likely be seen in the low flow characteristics, with a corresponding increase in streamflow deficits and deficit durations and a decrease in the time between deficit periods. These effects would also vary spatially within and between watersheds. We have seen that small, tile-drained subcatchments in Sangamon and Kaskaskia already experience smaller low flows than those without tile drainage. Because low flows in this region are dependent on shallow groundwater, such subcatchments would be more sensitive to the reduction in hillslope drainage that would result from planting Miscanthus. In tiledrained watersheds with surface water demands in upstream regions, such as Sangamon, this could reduce inflow to important water supply reservoirs; in Kaskaskia, however, these effects may be less noticeable because of the relative lack of tile drainage in the majority of headwater subcatchments.

\subsection{Study limitations and future work}

One limitation to this type of data-based analysis is that there are often too few gauges with sufficiently long periods of record upon which to base such analyses, thus creating "gaps" in the knowledge. This is where the large-scale watershed model becomes useful; once the basin is delineated into smaller sub-catchments, modeled streamflow information is then available at the outlet of each one, thereby greatly increasing the spatial resolution of the catchment response and allowing a more complete picture to emerge. Furthermore, the empirical analysis of these case study watersheds revealed that the past is not necessarily a deterministic predictor of the future because of the heterogeneous response created by the extensive drainage modifications to the system. However, understanding gained from such analysis can be used to guide the modeling process; thus both empirical and physically based modeling analyses are needed to make informed predictions about the possible effects of proposed land use changes. The next step, therefore, is to model this replacement of current row crop rotations with Miscanthus or other biomass energy crops.

The study region has a long history of human impacts and environmental feedbacks. Historically, the human response to these feedbacks has generally not been in a timely fashion, but rather has been motivated by dire conditions and directly addressed only to those conditions. The Dust Bowl, for example, led to adoption of soil management practices to reduce erosion throughout the Midwest, but little was done to address underlying water quality issues, although the development of the hypoxic "Dead Zone" in the Gulf of Mexico has brought water quality issues to the forefront. The new biofuel mandates prompting further land use change in this region have provided an opportunity to examine the problem from a broader perspective, considering the tradeoffs and possible solutions before a new set of dire conditions develops. Because the history of these two watersheds has highlighted the importance of environmental feedbacks and the need for a timely human response, we propose using a watershed model in an integrated systems model framework that allows for feedbacks between the human and the environmental systems. In this way, human actions impact the environment; these impacts in turn feed back onto the human system, which then must respond or find a solution. The observed data, then, is used not only for calibration, which can give the "right" answer for the wrong reasons (Kirchner, 2006), but also to gain a more fundamental understanding of 
the underlying processes controlling the catchment response (Klemeš, 1988).

\section{Conclusions}

This paper has presented a comparative study between two adjacent watersheds in the Midwestern US. Despite their close geographical proximity, the similar size of their drainage areas, and experiencing in general the same temperate climate, significant hydrologic differences were found both between the watersheds and within them. These differences are the result of both natural and human impacts to the region, with the major geologic difference being glacial history and the major anthropogenic differences being reservoirs, tile drainage, and land development. Although the general climate is similar, spatial variation in precipitation further increases the heterogeneity of the hydrologic response. The differences highlighted here are the result of the coevolution over time of the human and natural system and are thus relevant to any future changes that may be imposed on this coupled system.

Analyses of hydrologic signatures have revealed three main controls on the hydrologic response of these two watersheds. First, the precipitation inputs themselves are spatially and temporally variable in this region, and this area effect can be seen in both the annual and average monthly precipitation. At smaller timescales, this spatio-temporal variability can increase the heterogeneity of the catchment response due to the intensity of small convective storms common to this region. Second, the storage effects of inline reservoirs play a role in the catchment response of both watersheds. The storage in two large, main-stem flood control reservoirs in Kaskaskia is instrumental in reducing nitrate-N output from the watershed as well as reducing flow variability on controlled reaches, while the storage in smaller, municipal water supply reservoirs in Sangamon is diverted for human use, further reducing low flows and increasing the number of zeroflow days expected for the size of the drainage area. Third, at the scale of this study, tile drainage plays an extensive role in the catchment response in both watersheds, especially in the Sangamon, where a higher proportion of the land is tile drained. These effects manifest as a homogenous regime curve, increased heterogeneity in the low flows, and a higher $\mathrm{BI}$ relative to less-tiled areas. However, because tile drainage in this region is also generally associated with intensive rowcrop agriculture, it may be the combined effect of these land modifications that is being observed.

Analysis of the histories of the case study catchments shows that modifications and impacts have been layered on top of each other through time: fire, prairie conversion, surface drainage, subsurface (tile) drainage, reservoirs, intensification of row cropping, erosion, fertilizer application, etc. Spatially, this layering does not always follow watershed boundaries, but often human ones; resulting in the formation of a different mosaic of layers of change in each watershed. These mosaics of change, combined with the controls identified by analysis of the hydrologic signatures, is manifested in the summer low flow behavior, where greater variability in duration, frequency, and relative magnitude is associated with streamflow deficits in Sangamon compared to those in Kaskaskia. These differences would all affect the suitability of certain subcatchments for growing Miscanthus, and thus must be taken into account in future plans for biofuels expansion to avoid worsening or creating water stress conditions.

Acknowledgements. The research presented here was done as part of the NSF-funded project "Interdependence, Resilience, and Sustainability of Infrastructures for Biofuel Development" (NSF grant EFRI-083598, X. Cai, PI). We also wish to thank our anonymous referees for their insights and helpful criticism which have helped us improve this work.

Edited by: T. J. Troy

\section{References}

Baumhardt, R. L.: Dust Bowl era, in: Encyclopedia of Water Science, edited by: Stewart, B. A. and Howell, T. A., MarcelDekker, NY, 187-191, 2003.

Bogue, A.: From Prairie to Corn Belt: Farming on the Illinois and Iowa Prairies in the Nineteenth Century, Iowa State University Press, Ames, IA, 1994.

Bogue, M. B.: The Swamp Land Act and wet land utilization in Illinois, 1850-1890, Agr. Hist., 25, 169-180, 1951.

Cook, B. I., Miller, R. L., and Seager, R.: Amplification of the North American "Dust Bowl" drought through human-induced land degradation, P. Natl. Acad. Sci., 106, 4997-5001, 2009.

David, M. B., McIsaac, G. F., Royer, T. V., Darmody, R. G., and Gentry, L. E.: Estimated historical and current nitrogen balances for Illinois, Sci. World J., 1, 597-604, 2001.

David, M. B., Wall, L. G., Royer, T. V., and Tank, J. L.: Denitrification and the nitrogen budget of a reservoir in an agricultural landscape, Ecol. Appl., 16, 2177-2190, 2006.

David, M. B., Drinkwater, L. E., and McIsaac, G. F.: Sources of nitrate yields in the Mississippi River basin, J. Environ. Qual., 39, 1657-1667, 2010.

Donner, S. D. and Kucharik, C. J.: Corn-based ethanol production compromises goal of reducing nitrogen export by the Mississippi River, P. Natl Acad. Sci., 105, 4513-4518, 2008.

Donner, S. D. and Scavia, D.: How climate controls the flux of nitrogen by the Mississippi River and the development of hypoxia in the Gulf of Mexico, Limnol. Oceanogr., 52, 856-861, 2007.

Donner, S. D., Kucharik, C. J., and Foley, J. A.: Impact of changing land use practices on nitrate export by the Mississippi River, Global Biogeochem. Cy., 18, GB1028, doi:10.1029/2003GB002093, 2004.

Gentry, L. E., David, M. B., Below, F. E., Royer, T., and McIsaac, G F.: Nitrogen mass balance of a tile-drained agricultural watershed in East-Central Illinois, J. Environ. Qual., 38, 1841-1847, 2009.

Goolsby, D. A., Battaglin, W. A., Lawrence, G. B., Artz, R. S., Aulenbach, B. T., Hooper, R. P., Keeney, D. R., and Stensland, 
G. J.: Flux and sources of nutrients in the Mississipp-Atchafalaya River Basin, in: Topic 3 report for the integrated assessment on hypoxia in the Gulf of Mexico, NOAA Coastal Ocean Office, NOAA Coastal Ocean Program Analysis Series, Silver Springs, MD, 17, 130 pp., 1999.

Goswami, D., Kalita, P. K., Cooke, R. A., and Hirschi, M. C.: Estimation and analysis of baseflow in drainage channels in two tile-drained watersheds in Illinois, T. ASABE, 51, 1201-1213, 2008.

Heaton, E. A., Dohleman, F. G., and Long, S. P.: Meeting US biofuel goals with less land: the potential of Miscanthus, Glob. Change Biol., 14, 2000-2014, 2008.

Hickman, G. C., Vanloocke, A., Dohleman, F. G., and Bernacchi, C. J.: A comparison of canopy evapotranspiration for maize and two perennial grasses identified as potential bioenergy crops, GCB Bioenergy, 2, 157-168, 2010.

Hisdal, H. and Tallaksen, L. M.: Estimation of regional meteorological and hydrological drought characteristics: A case study for Denmark, J. Hydrol., 281, 230-247, 2003.

Jackson, L. L.: Restoring prairie processes to farmlands, in: The Farm as Natural Habitat, edited by: Jackson, D. L. and Jackson, L. L., Island Press, Washington, D.C., 2002.

Kalita, P. K., Algoazany, A. S., Mitchell, J. K., Cooke, R. A. C., and Hirschi, M. C.: Subsurface water quality from a flat tile-drained watershed in Illinois, USA, Agr. Ecosyst. Environ., 115, 183193, 2006.

Karlen, D. L., Dinnes, D. L., and Singer, J. W.: Midwest soil and water conservation: Past, present and future, in: Soil and Water Conservation Advances in the US: Past Effects - Future Outlook, edited by: Zobeck, T. M. and Schillinger, W. F., Soil Science Society of America, Inc., Madison, 131-162, 2010.

Keefer, L., Bauer, E., and Markus, M.: Hydrologic and Nutrient Monitoring of the Lake Decatur Watershed: Final Report 1993-2008, Illinois State Water Survey Contract Report 201007, Champaign, IL, 2010.

Kirchner, J. W.: Getting the right answers for the right reasons: Linking measurements, analyses, and models to advance the science of hydrology, Water Resour. Res., 42, W03S04, doi:10.1029/2005WR004362, 2006.

Klemeš, V.: A hydrological perspective, J. Hydrol., 100, 3-28, 1988.

Le, P. V. V., Kumar, P., and Drewry, D. T.: Implications for the hydrologic cycle under climate change due to the expansion of bioenergy crops in the Midwestern United States, P. Natl. Acad. Sci., 108, 15085-15090, 2011.

Martin, J.: Perspective: Don't foul the water, Nature, 474, p. S17, 2011.

McIsaac, G. F. and $\mathrm{Hu}, \mathrm{X}$.: Net $\mathrm{N}$ input and riverine $\mathrm{N}$ export from Illinois agricultural watersheds with and without extensive tile drainage, Biogeochemistry, 70, 251-271, 2004.

McIsaac, G. F., David, M. B., and Mitchell, C. A.: Miscanthus and switchgrass production in central Illinois: impacts on hydrology and inorganic nitrogen leaching, J. Environ. Qual., 39, 17901799, 2010.

Ng, T. L., Eheart, J. W., Cai, X., and Miguez, F.: Modeling Miscanthus in the Soil and Water Assessment Tool (SWAT) to simulate its water quality effects as a bioenergy crop, Environ. Sci. Technol., 44, 7138-7144, 2010.
Panno, S. V., Kelly, W. R., Hackley, K. C., Hwang, H.-H., and Martinsek, A.T.: Sources and fate of nitrate in the Illinois River Basin, Illinois, J. Hydrol., 359, 174-188, 2008.

Prince, H.: Wetlands of the American Midwest: A Historical Geography of Changing Attitudes, University of Chicago Press, Chicago, 1997.

Raymond P. A., David M. B., and Saiers J. E.: The impact of fertilization and hydrology on nitrate fluxes from Mississippi watersheds, Curr. Opin. Environ. Sustain., 4, 212-218, 2012.

Royer, T. V., Tank, J. L., and David, M. B.: Transport and fate of nitrate in headwater agricultural streams in Illinois, J. Environ. Qual. 33, 1296-1304, 2004.

Royer, T. V., David, M. B., and Gentry, L. E.: Timing of riverine export of nitrate and phosphorus from agricultural watersheds in Illinois: Implications for reducing nutrient loading to the Mississippi River, Environ. Sci. Technol., 40, 4126-4131, 2006.

Scavia, D. and Donnelly, K. A.: Reassessing hypoxia forecasts for the Gulf of Mexico, Environ. Sci. Technol., 41, 8111-8117, 2007.

Schilling, K. E., Jha, M. K., Zhang, Y. K., Gassman, P. W., and Wolter, C. F.: Impact of land use and land cover change on the water balance of a large agricultural watershed: Historical effects and future directions, Water Resour. Res., 44, W00A09, doi:10.1029/2007WR006644, 2008.

Schubert, S. D., Suarez, M. J., Pegion, P. J., Koster, R. D., and Bacmeister, J. T.: On the cause of the 1930s Dust Bowl, Science, 303, 1855-1859, 2004.

Smith, C. M., David, M. B., Mitchell, C. A., Masters, M. D., Anderson-Teixeira, K. J., Bernacchi, C. J., and DeLucia, E. H.: Reduced nitrogen losses after conversion of row crop agriculture to perennial biofuel crops, J. Environ. Qual., 42, 219-228, 2013.

Smith, R. A., Alexander, R. B., and Lanfear, K. J.: Stream water quality in the conterminous United States: Status and trends of selected indicators during the 1980s, in National Water Summary 1990-91: Hydrologic Events and Stream Water Quality, 111-140, USGS Water Supply Paper 2400, Washington, D.C., 1993.

Trimble, S. W.: Perspectives on the history of soil erosion control in the eastern United States, Agr. Hist., 59, 162-180, 1985.

Turner, R. E. and Rabalais, N. N.: Linking landscape and water quality in the Mississippi River basin for 200 years, BioScience, 53, 563-572, 2003.

Van der Velde, Y., Rozemeijer, J. C., De Rooij, G. H., Van Geer, F. C., and Broers, H. P.: Field- scale measurements for separation of catchment discharge into flow route contributions, Vadose Zone J., 9, 25-35, 2010.

Van Lanen, H. A. J., Wanders, N., Tallaksen, L. M., and Van Loon, A. F.: Hydrological drought across the world: impact of climate and physical catchment structure, Hydrol. Earth Syst. Sci., 17, 1715-1732, doi:10.5194/hess-17-1715-2013, 2013.

Vanloocke, A., Bernacchi, C. J., and Twine, T. E.: The impacts of Miscanthus x. giganteus production on the Midwest U.S. hydrologic cycle, Global Change Biology Bioenergy, 2, 180-191, 2010.

White, A. B., Kumar, P., Saco, P. M., Rhoads, B. L., and Yen, B. C.: Changes in hydrologic response due to stream network extension via land-drainage activities, J. Am. Water Res. As., 39, 15471560, 2003. 
Whitney, G. G.: From coastal wilderness to fruited plain: A history of environmental change in temperate North America from 1500 to the present, Cambridge University Press, Cambridge, 1994.

Woodhouse, C. A. and Overpeck, J. T.: 2000 years of drought variability in the central United States, B. Am. Meteorol. Soc., 79, 2693-2714, 1998.

Wooten, H. H. and Jones, L. A.: The history of our drainage enterprises, in Water, the yearbook of agriculture, U.S. Dept. of Agriculture, Washington, D.C., 478-491, 1955.

Wu, M., Demissie, Y., and Yan, E.: Simulated impact of future biofuel production on water quality and water cycle dynamics in the Upper Mississippi river basin, Biomass and Bioenergy, 41, 4456, 2012.

$\mathrm{Wu}$, Y. and Liu, S.: Impacts of biofuels production alternatives on water quantity and quality in the Iowa River Basin, Biomass Bioenerg., 36, 182-191, 2012.

Yaeger, M., Coopersmith, E., Ye, S., Cheng, L., Viglione, A., and Sivapalan, M.: Exploring the physical controls of regional patterns of flow duration curves - Part 4: A synthesis of empirical analysis, process modeling and catchment classification, Hydrol. Earth Syst. Sci., 16, 4483-4498, doi:10.5194/hess-16-44832012, 2012.
Ye, S., Yaeger, M., Coopersmith, E., Cheng, L., and Sivapalan, M.: Exploring the physical controls of regional patterns of flow duration curves - Part 2: Role of seasonality, the regime curve, and associated process controls, Hydrol. Earth Syst. Sci., 16, 44474465, doi:10.5194/hess-16-4447-2012, 2012.

Yevjevich, V.: An objective approach to definition and investigations of continental hydrologic droughts, Hydrology Papers 23, Colorado State University, Fort Collins, USA, 1967.

Yokoo, Y. and Sivapalan, M.: Towards reconstruction of the flow duration curve: development of a conceptual framework with a physical basis, Hydrol. Earth Syst. Sci., 15, 2805-2819, doi:10.5194/hess-15-2805-2011, 2011.

Zelenhasić, E. and Salvai, A.: A method of streamflow drought analysis, Water Resour. Res. 23, 156-168, 1987.

Zhang, Y.-K. and Schilling, K. E.: Increasing streamflow and baseflow in Mississippi River since the 1940s: Effect of land use change, J. Hydrol., 324, 412-422, 2006. 